\title{
Spectroscopic Investigations, Anti-bacterial Activities and DNA-interactions of Metal Complexes (Cr(III), Zn(II), Ni(II)) Containing Phendione Ligand
}

\author{
M. A. Subhan ${ }^{1 *}$, F. Ahmed ${ }^{1}$, M. S. Rahaman', A. K. Azad' ${ }^{2}$, K. Begum ${ }^{2}$ \\ ${ }^{1}$ Department of Chemistry, Shah Jalal University of Science and Technology, Sylhet, Bangladesh \\ ${ }^{2}$ Deparment of Biotechnology and Genetic Engineering, Shah Jalal University of Science and \\ Technology, Sylhet, Bangladesh
}

Received 9 May 2015, accepted in final revised form 11 June 2015

\begin{abstract}
The transition metal complexes [ $\mathrm{Cr}(\mathrm{acac})_{2}$ (phendione)]Cl, [Zn(acac) ${ }_{2}$ (phendione)], $\left.\left[\mathrm{Ni}(\mathrm{acac})_{2} \text { (phendione)], [Zn(phendione }\right)_{3}\right]\left(\mathrm{ClO}_{4}\right)_{2}$ and $\left.[\mathrm{Ni} \text { (phendione })_{2}\right]\left(\mathrm{ClO}_{4}\right)_{2}$ were synthesized from 1, 10-phenanthroline-5, 6-dione (phendione). The phendione ligands and its metal complexes were characterized by FTIR, UV-Visible spectroscopy, PL study and in some cases by GC-MS. The red emission band of complex [Zn(acac) 2 (phendione)] was observed by excitation at $250 \mathrm{~nm}$. DNA binding activities of the complexes were studied by DNA Gel Electrophoresis. DNA binding studies of the synthesized compounds showed that the metal complexes are strong DNA binding and cleaving agents. The [Ni(phendione $)_{2}$ ] $\left(\mathrm{ClO}_{4}\right)_{2}$ complex was the most effective DNA binding and cleaving agent and $\left[\mathrm{Cr}(\mathrm{acac})_{2}\right.$ (phendione) $] \mathrm{Cl}$ complex shows relatively lower affinity to the DNA. The metal complexes easily cause DNA degradation or cleavage (after $2.5 \mathrm{~h}$ ) with genomic DNA rather than plasmid DNA. Antimicrobial activity studies revealed that all metal complexes of phendione showed efficient resistance to bacteria. The $\left[\mathrm{Cr}(\mathrm{acac})_{2}\right.$ (phendione)]Cl complex showed most potential antimicrobial activities against the bacteria Escherichia coli with an annular radius of the inhibitory zone, 4.33.
\end{abstract}

Keywords: Phendione; Metal complex of phendione; DNA binding; Anti-microbial; Photoluminescence.

$\begin{aligned} & \text { 〔) } 2015 \text { JSR Publications. ISSN: 2070-0237 (Print); 2070-0245 (Online). All rights reserved. } \\ & \text { doi: http://dx.doi.org/10.3329/jsr.v7i3.23270 }\end{aligned}$

\section{Introduction}

The development of new materials that exhibit extensive optical and biological activities such as DNA binding, DNA cleaving, antimicrobial sensibility have become potential for the last few decades in the medicinal and pharmaceutical fields. The metal complexes with the ligand containing heterocyclic ring systems are very promising candidates for such applications [1-17]. The ongoing interests in the pharmacological field for the

* Corresponding author: subhan-che@sust.edu 
development of better therapeutic agents which can bind and damage DNA is rationalized by the fact that many diseases, including cancer occur because of aberrant gene expression. Transition metal complexes are the potential candidates in this field due to their tunable coordination environments and versatile physiochemical properties for designing highly sensitive diagnostic agents for medicinal applications as exemplified by the chemotherapeutic agents like the cis-platin or bleomycins. In our present work we intended to synthesize some transition metal complexes containing phendione. We have chosen 3d transition metals namely $\mathrm{Cr}$, Zn, and Ni because these metals are bio-essential and ubiquitous in biological systems. The reason for choosing the phendione ligand is that metal complexes of this ligand have been reportedly show huge biological activities such as DNA binding and damaging activities and also their metal complexes have been reported to show NLO (Nonlinear Optical) properties for device applications. In addition phendione is an amazing chelating ligand that can form monomeric as well as polymeric coordination complexes. The term "phenanthroline" is used to denote any one of the three heterocyclic ring systems. Our recent study is concerning phendione ligands, which is originated from phenanthroline [2,3]. Phendione based metal complex chemistry has been growing rapidly due to promising electrical, optical and biological applications [4-23]. In our present study we reported the synthesis of several metal complexes containing phendione ligand with their characterization, optical as well as biological properties.

\section{Experimental}

\subsection{Materials and methods}

$\mathrm{NiCl}_{2} \cdot 6 \mathrm{H}_{2} \mathrm{O}, \mathrm{ZnCl}_{2}$, phenanthroline and solvents were purchased from E. Merck, Germany and used as supplied. Phendione was synthesized according to the method available in literature [24]. GC-MS (GC/MSD, Agilent, USA), spectroflurophotometer (Shimadzu Corp., model RF-5301), UV-Visible spectrophotometer (UV-1800, Shimadzu, Japan) and FTIR spectrometer (IP Prestidge-21, Shimadzu, Japan) were used for the characterization of metal complexes.

\subsection{Synthesis of $\left[\mathrm{Cr}(\mathrm{acac})_{2}\right.$ (phendione)]Cl complex}

[Cr(acac $\left.)_{2} \mathrm{Cl}\right] \cdot 2 \mathrm{H}_{2} \mathrm{O}$ was synthesized using a similar method [25]. In an ethanolic solution of [Cr(acac $\left.)_{2} \mathrm{Cl}\right] \cdot 2 \mathrm{H}_{2} \mathrm{O}(0.020 \mathrm{~g}, 0.07 \mathrm{mmol})$ taken in a round bottomed flask a chloroform solution of phendione $(0.0148 \mathrm{~g}, 0.07 \mathrm{mmol})$ was added drop wise. This solution was stirred at room temperature for $6 \mathrm{~h}$. After completion of the reaction the solution was kept for the evaporation of the solvent or solvent was reduced by a rotary evaporator and allowed to stand for several days. This was collected by filtration and washed with dichloromethane and recrystallized from methanol. GC-MS peak was observed at $\mathrm{m} / \mathrm{z}$ 435. 


\subsection{Synthesis of [Zn(acac) ${ }_{2}$ (phendione)] complex}

$\mathrm{Zn}$ (acac) $)_{2} \cdot \mathrm{H}_{2} \mathrm{O}$ was synthesized according to the literature [26]. In an ethanolic solution of $\mathrm{Zn}(\text { acac })_{2} \cdot \mathrm{H}_{2} \mathrm{O}(0.01248 \mathrm{~g}, 0.07 \mathrm{mmol})$ taken in a round bottomed flask a chloroform solution of phendione $(0.0148 \mathrm{~g}, 0.07 \mathrm{mmol})$ was added drop wise. This solution was stirred at room temperature for $6 \mathrm{~h}$. After completion of the reaction the solution was kept for the evaporation of the solvent or solvent was reduced by a rotary evaporator and allowed to stand for several days. This was collected by filtration and washed with chloroform. GC-MS peak was observed at m/z 447.

\subsection{Synthesis of $\left[\mathrm{Ni}(\mathrm{acac})_{2}\right.$ (phendione)] complex}

$\mathrm{Ni}(\mathrm{acac})_{2} \cdot 2 \mathrm{H}_{2} \mathrm{O}$ was synthesized according to the literature method [27]. In an ethanolic solution of $\mathrm{Ni}(\mathrm{acac})_{2} \cdot 2 \mathrm{H}_{2} \mathrm{O}(0.01362 \mathrm{~g}, 0.07 \mathrm{mmol})$ in a round bottomed flask a chloroform solution of phendione $(0.0148 \mathrm{~g}, 0.07 \mathrm{mmol})$ was added drop wise. This solution was stirred at room temperature for $6 \mathrm{~h}$. After completion of the reaction the solution was kept for the evaporation of the solvent or solvent was reduced by a rotary evaporator and allowed to stand for several days. This was collected by filtration and washed with chloroform. GC-MS was observed at m/z 441.

\subsection{Synthesis of $\left[\mathrm{Zn}(\text { phendione })_{3}\right]\left(\mathrm{ClO}_{4}\right)_{2}$ complex}

In an aqueous solution of $\mathrm{ZnCl}_{2}(137 \mathrm{mg}, 1 \mathrm{mmol})$ taken in a round bottomed flask $20 \mathrm{~mL}$ ethanolic solution of phendione (157.5 mg, $3 \mathrm{mmol}$ ) was slowly added. The resulting solution was stirred at room temperature for $24 \mathrm{~h}$. The complex was precipitated as a pale yellow solid by addition of sodium perchlorate $(150 \mathrm{mg}, 3 \mathrm{mmol})$. The product [Zn(phendione) $\left.)_{3}\right]\left(\mathrm{ClO}_{4}\right)_{2}$ was collected by suction filtration, washed with cold water and diethylether and then air dried [28].

\subsection{Synthesis of [Ni (phendione $\left.)_{2}\right]\left(\mathrm{ClO}_{4}\right)_{2}$ complex}

In an aqueous solution of $\mathrm{NiCl}_{2} \cdot 6 \mathrm{H}_{2} \mathrm{O}(59.42 \mathrm{mg}, 1 \mathrm{mmol})$ taken in a round bottomed flask a $20 \mathrm{~mL}$ solution of 1,10-phenanthroline-5, 6-dione (157.5 mg, $2 \mathrm{mmol}$ ) was slowly added. The resulting solution was stirred at room temperature for $24 \mathrm{~h}$. The complex was precipitated as a light yellow solid by addition of sodium perchlorate (150 mg, $3 \mathrm{mmol}$ ). The product $\left[\mathrm{Ni}(\text { phendione })_{3}\right]\left(\mathrm{ClO}_{4}\right)_{2}$ was collected by suction filtration, washed with cold water and diethylether and then air dried [28].

\subsection{Antimicrobial activities study}

Antimicrobial activities of the synthesized metal complexes were performed against both Gram-negative (Eschericha coli, Proteus mirabilis, klebsiella pneumonia and 
pseudomonas aeruginosa) and Gram-positive (Staphylococcus aureus) bacteria. The antibacterial activity was studied by modified Kirby-Bauer disk diffusion method. In brief, the pure cultures of organisms were sub cultured in nutrient broth at $37^{\circ} \mathrm{C}$ on a rotary shaker at $120 \mathrm{rpm}$. For bacterial growth, a lawn of culture was prepared by spreading the $20 \mu \mathrm{L}$ fresh culture having $10^{6}$ colony-forming units (CFU)/mL of each test organism on nutrient agar plates with the help of a sterile glass-rod spreader. Plates were left standing for $10 \mathrm{~min}$ to let the culture get absorbed. Then $6 \mathrm{~mm}$ wells were punched into the nutrient agar plates for testing antimicrobial activity. Wells were sealed with one drop of molten agar ( $0.8 \%$ agar) to prevent leakage of compounds from the bottom of the wells. Using a micropipette, $50 \mu \mathrm{L}(500 \mu \mathrm{g})$ of the sample compounds suspension was poured onto each of five wells on all plates. After overnight incubation at $37^{\circ} \mathrm{C}$ the different levels of zones of inhibitions were measured [29].

\section{Results and Discussions}

Phendione was synthesized by the oxidation of 1, 10-phenanthrolines using $\mathrm{KBr}$ and mixture of conc. sulfuric and nitric acids as oxidant. Characterization of phendione was accomplished by melting point, UV-visible and IR spectroscopic methods. Our results matched well with those of literature [8]. Melting point of phendione was found to be 258$260^{\circ} \mathrm{C}$ which is consistence with the literature. The electronic spectrum of phendione recorded in acetone solution exhibited two absorption bands in the UV region. The absorption band at $359 \mathrm{~nm}$ is assigned to $\mathrm{n} \rightarrow \pi^{*}$ of $\mathrm{C}=\mathrm{N}$ bonds. The strong absorption band centered at $451 \mathrm{~nm}$ is assigned to $\mathrm{n} \rightarrow \pi^{*}$ of the $\mathrm{C}=\mathrm{O}$ group of phendione ligand. IR spectrum of phendione clearly exhibited characteristic peaks at $1688 \mathrm{~cm}^{-1}$ and at $1564 \mathrm{~cm}^{-}$ ${ }^{1}$ which are ascribable to a stretching frequency of the $\mathrm{C}=\mathrm{O}$ and $\mathrm{C}=\mathrm{N}$ bands respectively in the ligand [9].

In chromium complex [ $\left.\mathrm{Cr}(\mathrm{acac})_{2} \mathrm{Cl}\right] \cdot 2 \mathrm{H}_{2} \mathrm{O}$ characteristic absorption peaks appeared at around $535 \mathrm{~nm}$ and $388 \mathrm{~nm}$ can be assigned to $\mathrm{E} \rightarrow \mathrm{T}_{2 \mathrm{~g}}$ and $\mathrm{n} \rightarrow \pi *$ transitions respectively. For the $\left[\mathrm{Cr}(\mathrm{acac})_{2}\right.$ (phendione)]Cl complex the characteristic absorption peaks at around $541 \mathrm{~nm}$ and $451 \mathrm{~nm}$ can be assigned to the $\mathrm{E} \rightarrow \mathrm{T}_{2 \mathrm{~g}}$ and $\mathrm{n} \rightarrow \pi^{*}$ transitions respectively (Fig. 1). This confirms the presence of chromium in the complex.

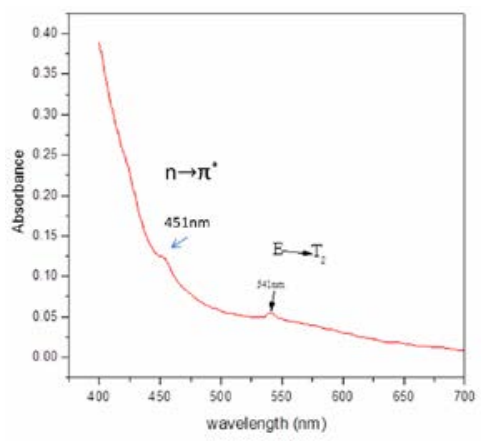

Fig. 1. Absorption spectra for the $\left[\mathrm{Cr}(\mathrm{acac})_{2}\right.$ (phendione) $] \mathrm{Cl}$ complex. 
The FTIR spectrum of phendione clearly exhibited stretching frequency of the $\mathrm{C}=\mathrm{O}$ band at $1689 \mathrm{~cm}^{-1}$. This band is shifted in the $\left[\mathrm{Cr}(\mathrm{acac})_{2}\right.$ (phendione)]Cl complex and found at $1703 \mathrm{~cm}^{-1}$ which is reasonable since the $\mathrm{C}=\mathrm{O}$ moieties are far removed from the site of coordination of this ligand with the metal ion [9,10]. In IR spectrum of the starting chromium complex [Cr(acac $\left.)_{2} \mathrm{Cl}\right] \cdot 2 \mathrm{H}_{2} \mathrm{O}$ this new band is absent, which confirms the presence of phendione in the $\left[\mathrm{Cr}(\mathrm{acac})_{2}\right.$ (phendione) $] \mathrm{Cl}$ complex.

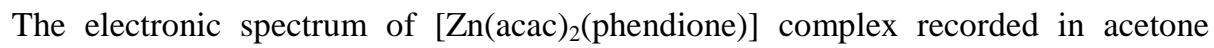
solution exhibited two absorption bands in the UV-Visible region. The absorption band at $325 \mathrm{~nm}$ (a) is assigned to $\mathrm{n} \rightarrow \pi^{*}$ of $\mathrm{C}=\mathrm{N}$ bonds. The strong absorption band centered at $451 \mathrm{~nm}$ (b) is assigned to $\mathrm{n} \rightarrow \pi^{*}$ of the $\mathrm{C}=0$ group of phendione ligand (Fig. 2).

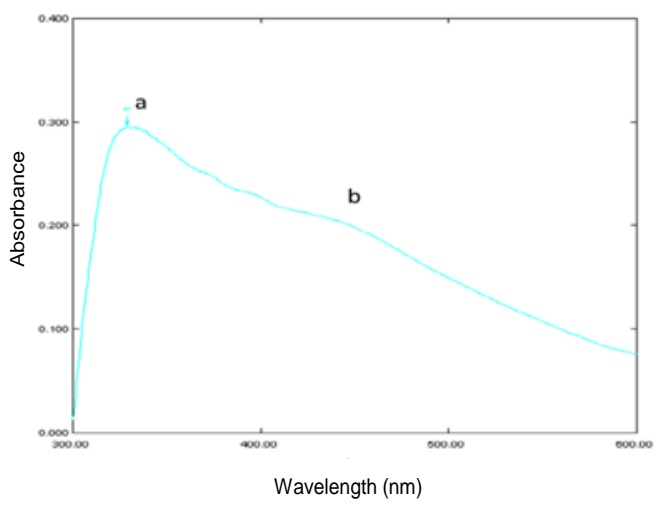

Fig. 2. Absorption spectra for the $\left[\mathrm{Zn}(\mathrm{acac})_{2}\right.$ (phendione)] complex.

The $\mathrm{C}=\mathrm{O}$ band is also found to be shifted in the $\left[\mathrm{Zn}(\mathrm{acac})_{2}\right.$ (phendione)] complex compared to that of phendione and found at $1716 \mathrm{~cm}^{-1}$. In IR spectrum of the starting complex $\mathrm{Zn}(\mathrm{acac})_{2} \cdot 2 \mathrm{H}_{2} \mathrm{O}$ this band is not observed. It may prove the presence of phendione in coordination to $\mathrm{Zn}$ (II) in the [Zn(acac) ${ }_{2}$ (phendione)] complex (Fig. 3).

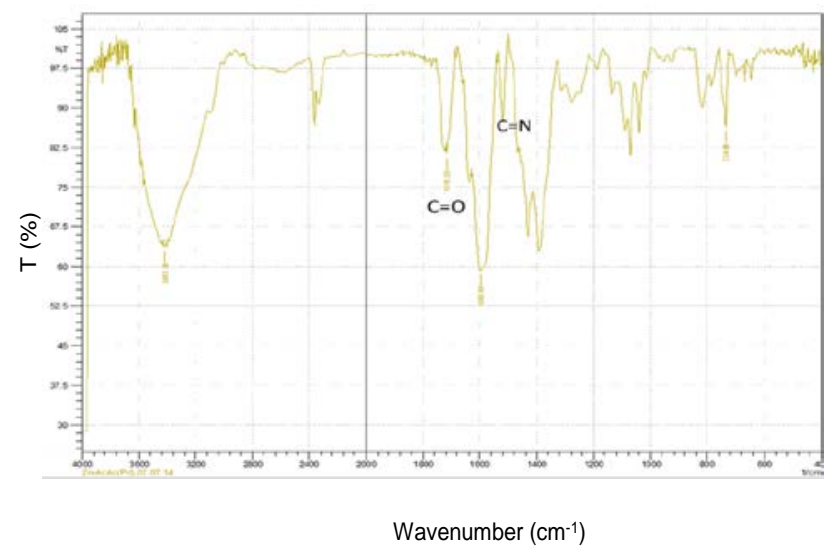

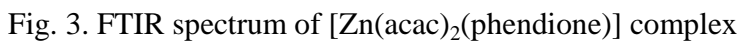


[ $\mathrm{Zn}$ (phendione $\left.)_{3}\right]\left(\mathrm{ClO}_{4}\right)_{2}$ complex was synthesized by the reaction of $\mathrm{ZnCl}_{2} \cdot 6 \mathrm{H}_{2} 0$ and phendione maintaining a molar ratio of $1: 3$. The electronic spectrum of the complex that was recorded in acetonitrile solution (Fig. 4) exhibited one band in the visible region and three absorption bands in the UV region. The strong absorption band centered at $487 \mathrm{~nm}$ (a) is assigned to $\mathrm{n} \rightarrow \pi^{*}$ of the $\mathrm{C}=\mathrm{O}$ group of phendione ligand. The three bands centered at 253, 293 and $314 \mathrm{~nm}(\mathrm{~b})$ are assigned to ligand centered $\left(\pi \rightarrow \pi^{*}\right)$ transitions [6,20-22]. The solvent dependency of $n \rightarrow \pi *$ energy on the solvent polarity, a well known phenomenon, is the reason behind such an assignment $[17,22]$.

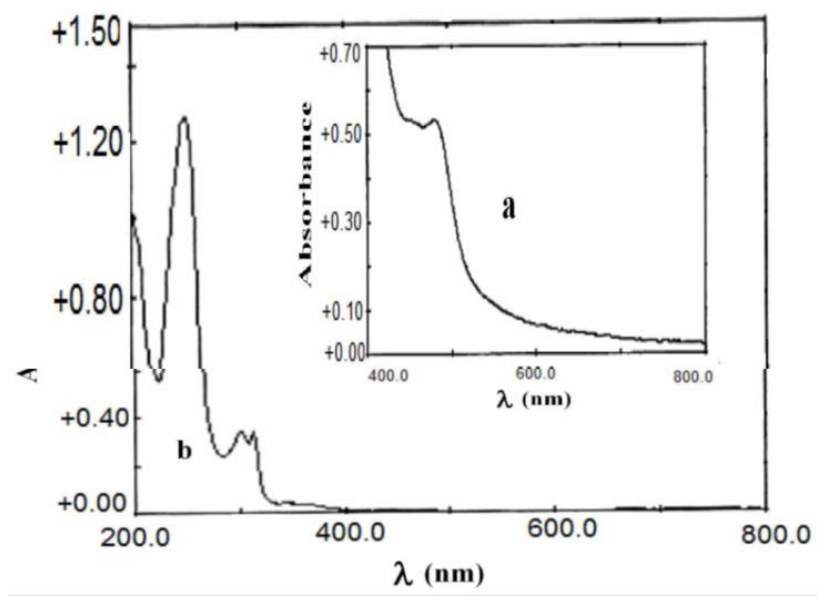

Fig. 4. UV-Visible absorption spectrum of $\mathrm{Zn}$ (phendione) $\left.)_{3}\right]\left(\mathrm{ClO}_{4}\right)_{2}$ complex.

Compared with that of $\mathrm{Zn}(\mathrm{acac})_{2} \cdot 2 \mathrm{H}_{2} \mathrm{O}$ complex the FTIR spectrum of the $\left.[\mathrm{Zn} \text { (phendione) })_{3}\right]\left(\mathrm{ClO}_{4}\right)_{2}$ complex confirms the existence of the phendione ligand. The IR band is observed to be shifted in the $\left.[\mathrm{Zn} \text { (phendione) })_{3}\right]\left(\mathrm{ClO}_{4}\right)_{2}$ complex and found at 1696 $\mathrm{cm}^{-1}$ compared to the $\mathrm{C}=\mathrm{O}$ band of phendione at $1689 \mathrm{~cm}^{-1}$. This band is absent in starting $\mathrm{Zn}(\mathrm{acac})_{2} \cdot 2 \mathrm{H}_{2} \mathrm{O}$ complex, which proves the presence of phendione in $\left.[\mathrm{Zn} \text { (phendione })_{3}\right]\left(\mathrm{ClO}_{4}\right)_{2}$. Besides, the very strong absorption at around $640 \mathrm{~cm}^{-1}$, the bands at $940 \mathrm{~cm}^{-1}$ and $1090 \mathrm{~cm}^{-1}$ are assigned to $v_{\text {as }}\left(\mathrm{ClO}_{4}^{-}\right), v_{\mathrm{s}}\left(\mathrm{ClO}_{4}^{-}\right)$and $\delta\left(\mathrm{ClO}_{4}^{-}\right)$of ionic perchlorate in $\left.[\mathrm{Zn} \text { (phendione })_{3}\right]\left(\mathrm{ClO}_{4}\right)_{2}$.

[Ni(phendione $\left.)_{2}\right]\left(\mathrm{ClO}_{4}\right)_{2}$ complex was synthesized by the reaction of $\mathrm{NiCl}_{2} \cdot 6 \mathrm{H}_{2} \mathrm{O}$ and phendione with a molar ratio of 1:2. For nickel complex [Ni(phendione $\left.)_{2}\right]\left(\mathrm{ClO}_{4}\right)_{2}$, the characteristic absorption peaks appeared at around 320, 438 and $474 \mathrm{~nm}$ are assigned to the ${ }^{3} \mathrm{~A}_{2 \mathrm{~g}} \rightarrow{ }^{3} \mathrm{~T}_{2 \mathrm{~g}}(\mathrm{P}),{ }^{3} \mathrm{~A}_{2 \mathrm{~g}} \rightarrow{ }^{3} \mathrm{~T}_{1 \mathrm{~g}}$ and ${ }^{3} \mathrm{~A}_{2 \mathrm{~g}} \rightarrow{ }^{3} \mathrm{~T}_{2 \mathrm{~g}}(\mathrm{~F})$ transitions respectively (Fig. 5). This may prove the presence of $\mathrm{Ni}(\mathrm{II})$ in the complex.

IR spectra of $\left.[\mathrm{Ni} \text { (phendione })_{2}\right]\left(\mathrm{ClO}_{4}\right)_{2}$ and $\mathrm{Ni}(\mathrm{acac})_{2} \cdot 2 \mathrm{H}_{2} \mathrm{O}$ were recorded for comparison. The IR spectrum of phendione clearly exhibited stretching frequency of the $\mathrm{C}=\mathrm{O}$ band at $1689 \mathrm{~cm}^{-1}$. This band is shifted in the $\left.[\mathrm{Ni} \text { (phendione })_{2}\right]\left(\mathrm{ClO}_{4}\right)_{2}$ complex compared to that of phendione and appeared at $1701 \mathrm{~cm}^{-1}$. This band is not found in $\mathrm{Ni}(\mathrm{acac})_{2} \cdot 2 \mathrm{H}_{2} \mathrm{O}$, which proves the presence of phendione in coordination to $\mathrm{Ni}(\mathrm{II})$ in the 
complex $\left[\mathrm{Ni}(\text { phendione })_{2}\right]\left(\mathrm{ClO}_{4}\right)_{2}$. The very strong absorption at around $620 \mathrm{~cm}^{-1}, 930 \mathrm{~cm}^{-}$ ${ }^{1}$ and $1088 \mathrm{~cm}^{-1}$ are assigned to $v_{\mathrm{as}}\left(\mathrm{ClO}_{4}^{-}\right), v_{\mathrm{s}}\left(\mathrm{ClO}_{4}^{-}\right)$and $\delta\left(\mathrm{ClO}_{4}^{-}\right)$of ionic perchlorate in $\left[\mathrm{Ni}(\text { phendione })_{2}\right]\left(\mathrm{ClO}_{4}\right)_{2}$.

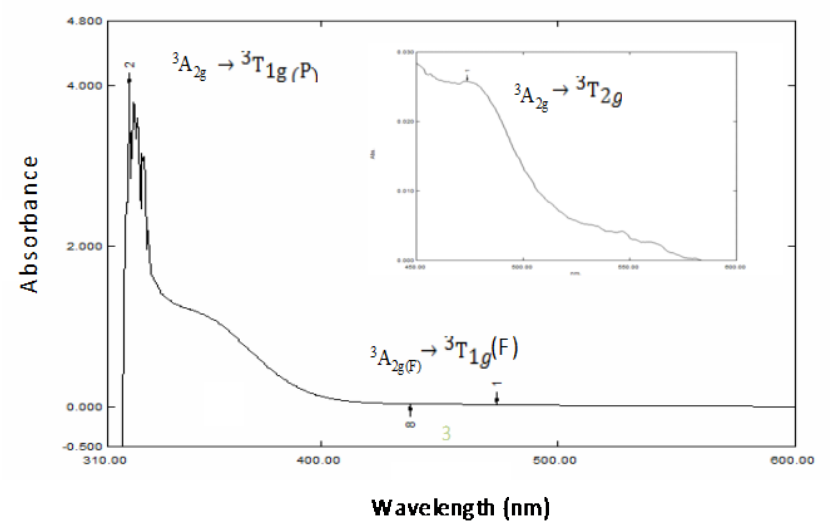

Fig. 5. UV-Visible absorption spectrum of [Ni(phendione $\left.)_{2}\right]\left(\mathrm{ClO}_{4}\right)_{2}$ complex.

[Ni(acac) $)_{2}$ (phendione)] complex was synthesized by the reaction of $\mathrm{Ni}(\mathrm{acac})_{2} \cdot 2 \mathrm{H}_{2} \mathrm{O}$ and phendione using a molar ratio of 1:1. For nickel complex [Ni(phendione $\left.)_{2}\right]\left(\mathrm{ClO}_{4}\right)_{2}$ the characteristic absorption peaks at 311, 500 and $656 \mathrm{~nm}$ are assigned to (a) ${ }^{3} \mathrm{~A}_{2 \mathrm{~g}} \rightarrow{ }^{3} \mathrm{~T}_{2 \mathrm{~g}}(\mathrm{P})$, (b) ${ }^{3} \mathrm{~A}_{2 g} \rightarrow{ }^{3} \mathrm{~T}_{1 \mathrm{~g}}$ and (c) ${ }^{3} \mathrm{~A}_{2 \mathrm{~g}} \rightarrow{ }^{3} \mathrm{~T}_{2 \mathrm{~g}}(\mathrm{~F})$ transitions respectively (Fig. 6). This may reveal the presence of nickel(II) in the complex.

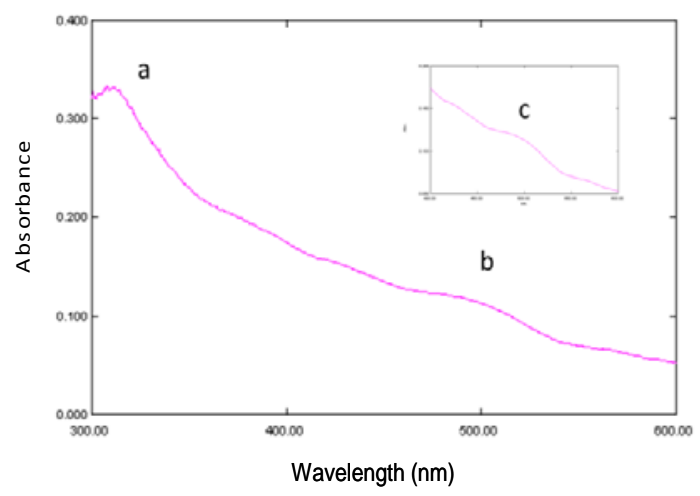

Fig. 6. Absorption spectra for the $\left[\mathrm{Ni}(\mathrm{acac})_{2}\right.$ (phendione)] complex.

The IR spectrum of phendione exhibited stretching frequency of the $\mathrm{C}=\mathrm{O}$ band at

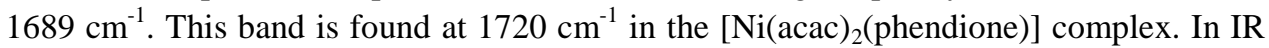
spectrum of the starting $\mathrm{Ni}(\mathrm{II})$ complex $\mathrm{Ni}(\text { acac })_{2} \cdot 2 \mathrm{H}_{2} \mathrm{O}$ this band is absent. This may

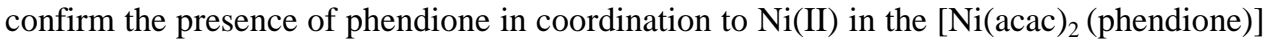


complex. Thus, IR as well as UV-Visible spectra studies confirmed the formation of metal complexes with phendione and acac ligands.

\subsection{PL spectra of phendione complexes}

\subsubsection{PL spectra of $\left[\mathrm{Cr}(\text { acac })_{2}\right.$ (phendione) $] \mathrm{Cl}$ complex}

Photoluminescence (PL) spectra of $\left[\mathrm{Cr}(\mathrm{acac})_{2}\right.$ (phendione) $] \mathrm{Cl}$ complex were measured in acetone (Fig. 7). Emission bands are observed at 408, 432 and $455 \mathrm{~nm}$ when excited at $373 \mathrm{~nm}$ [21]. The blue emission band is found at $432 \mathrm{~nm}$. Blue emission of metal complex is also observed at 468 and green at $500 \mathrm{~nm}$ when excited at $434 \mathrm{~nm}$.

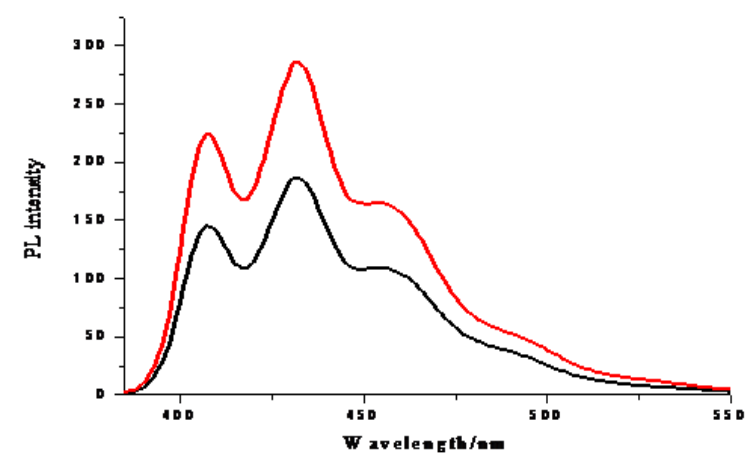

Fig. 7. PL spectra of $\left[\mathrm{Cr}(\mathrm{acac})_{2}\right.$ (phendione)]Cl complex when excited at 373 (red) and $434 \mathrm{~nm}$ (black).

\subsection{2. $\quad$ PL spectra of Zn (II) complex}

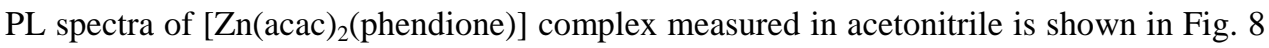
and Table 1. Several emission bands are observed at 406, 439, 445, 585, 614 and $659 \mathrm{~nm}$ when excited at $220 \mathrm{~nm}$ [21]. Blue emissions are observed at 406, 439 and $445 \mathrm{~nm}$. Orange emission is observed at $585 \mathrm{~nm}$. Red emissions are observed at 614 and $659 \mathrm{~nm}$ at NIR region (Fig. 8). This indicates that [Zn(acac) ${ }_{2}$ (phendione)] complex has an octahedral structure. Emission bands are observed at 405, 428, 502 and $618 \mathrm{~nm}$ when excited at 250 $\mathrm{nm}$ [21]. Blue emissions are observed at 405 and $428 \mathrm{~nm}$. Green emission is observed at $502 \mathrm{~nm}$. Strong blue emission is observed at $405 \mathrm{~nm}$. Red emission is observed at $618 \mathrm{~nm}$ (NIR region), which also indicates that [Zn(acac) ${ }_{2}$ (phendione)] complex has an octahedral structure. Emission bands are observed at around 403, 428, 585, 620 and $670 \mathrm{~nm}$ when excited at $280 \mathrm{~nm}$ [21]. Blue emissions are observed at 403 and $428 \mathrm{~nm}$. Orange emission is observed at $585 \mathrm{~nm}$. Red emissions are observed at 620 and $670 \mathrm{~nm}$. Strong blue emission is observed at $403 \mathrm{~nm}$. Emission bands are observed at 407, 430 and $465 \mathrm{~nm}$ when excited at $370 \mathrm{~nm}$ [21]. Thus [Zn(acac) ${ }_{2}$ (phendione)] complex showed blue 
emissions when excited at longer wavelength and red emissions when excited at shorter wavelength region. PLE (Photoluminescence Excitation) bands are also observed at around 360, 370 and $395 \mathrm{~nm}$ when monitored at $507 \mathrm{~nm}$ [21].

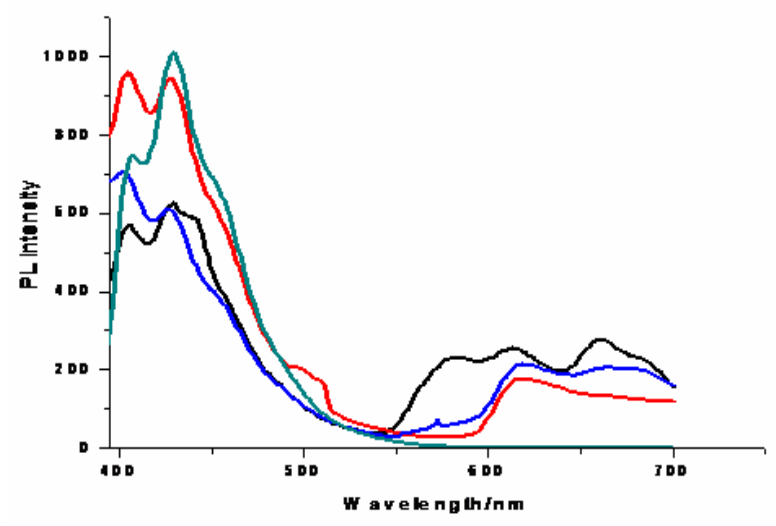

Fig. 8. PL spectra of $\left[\mathrm{Zn}(\mathrm{acac})_{2}\right.$ (Phendione)] complex when excited at $220 \mathrm{~nm}$ (black), $250 \mathrm{~nm}$ (red), $280 \mathrm{~nm}$ (blue) and $370 \mathrm{~nm}$ (green).

Table 1. PL spectra result of [Zn(acac) ${ }_{2}$ (phendione)] complex.

\begin{tabular}{ll}
\hline Excitation wavelength (nm) & Emission observed (nm) \\
\hline 220 & $406,439,445,585,614$ and 659 \\
250 & $405,428,502$ and 618 \\
280 & $403,428,585,620$ and 670 \\
370 & 407,430 and 465 \\
\hline
\end{tabular}

\subsubsection{PL spectra of $\left[\mathrm{Zn}(\text { phendione })_{3}\right]\left(\mathrm{ClO}_{4}\right)_{2}$ complex}

PL spectra of [ $\mathrm{Zn}$ (phendione) $\left.)_{3}\right]\left(\mathrm{ClO}_{4}\right)_{2}$ complex was measured in acetone. Emission bands are observed at 402, 427 and $453 \mathrm{~nm}$ when excited at $370 \mathrm{~nm}$ (Fig. 9) and $410 \mathrm{~nm}$ [21]. The strong blue emission band at $427 \mathrm{~nm}$ is observed. PLE spectrum with several bands at 350, 375, 395, 428 and $461 \mathrm{~nm}$ are observed when monitored at $510 \mathrm{~nm}$ (Fig. 10).

\subsubsection{PL spectra of [Ni(phendione $\left.)_{2}\right]\left(\mathrm{ClO}_{4}\right)_{2}$ complex}

PL spectra of [Ni(phendione) $\left.)_{2}\right]\left(\mathrm{ClO}_{4}\right)_{2}$ complex was also measured in acetone (Fig. 11). Emission bands are observed at 403, 430 and $454 \mathrm{~nm}$ when excited at $355 \mathrm{~nm}$ [21]. The blue emission bands are observed at 430 and $454 \mathrm{~nm}$. The complex also showed emission bands at $374 \mathrm{~nm}$ in UV region and at $403 \mathrm{~nm}$ in visible regions (violet emission). 


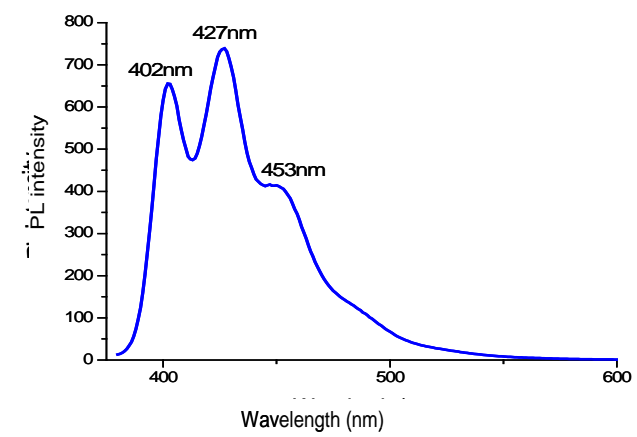

Fig. 9. PL spectrum of $\left[\mathrm{Zn}(\text { phendione })_{3}\right]\left(\mathrm{ClO}_{4}\right)_{2}$ complex when excited at $370 \mathrm{~nm}$.

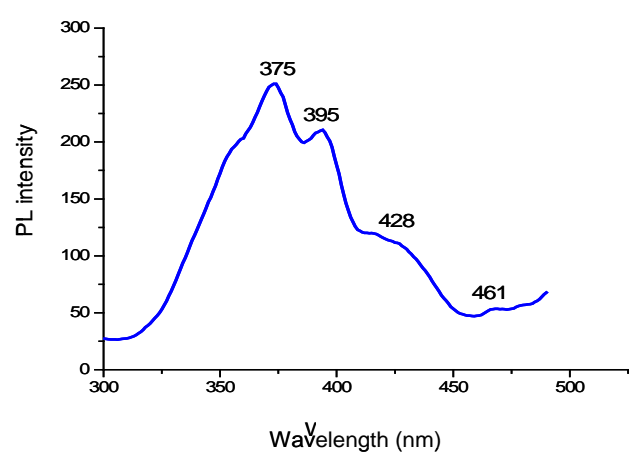

Fig. 10. PLE spectrum of $\left[\mathrm{Zn}(\text { phendione })_{3}\right]\left(\mathrm{ClO}_{4}\right)_{2}$ complex when monitored at $510 \mathrm{~nm}$.

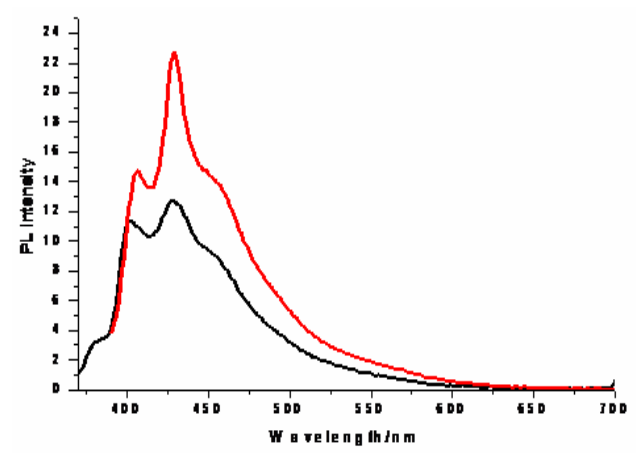

Fig. 11. PL spectra of $\left[\mathrm{Ni}(\text { phendione })_{2}\right]\left(\mathrm{ClO}_{4}\right)_{2}$ complex when excited at 355 (black) and $379 \mathrm{~nm}$ (red).

Emission bands are observed at 406, 429 and $460 \mathrm{~nm}$ when excited at $379 \mathrm{~nm}$ [21]. The blue emission bands are observed at 406, 429 and $460 \mathrm{~nm}$. PLE bands are observed at 332, 379 and $392 \mathrm{~nm}$ when monitored at $429 \mathrm{~nm}$ [21]. This complex showed PL spectra mostly in visible region. 


\subsection{5. $\mathrm{PL}$ spectra of $\left[\mathrm{Ni}(\text { acac })_{2}\right.$ (phendione)] complex}

PL spectra of $\left[\mathrm{Ni}(\mathrm{acac})_{2}\right.$ (phendione)] was measured in acetonitrile (Fig. 12). Emission bands are observed at around 335, 395 and $435 \mathrm{~nm}$ when excited at $298 \mathrm{~nm}$ [21]. The strongest blue emission band is observed at around $435 \mathrm{~nm}$. The emission bands of metal complex are observed at 360, 370, 410, 428 and $455 \mathrm{~nm}$ when excited at $340 \mathrm{~nm}$. Excitation at $410 \mathrm{~nm}$ provided emissions at 440, 453 and $470 \mathrm{~nm}$.

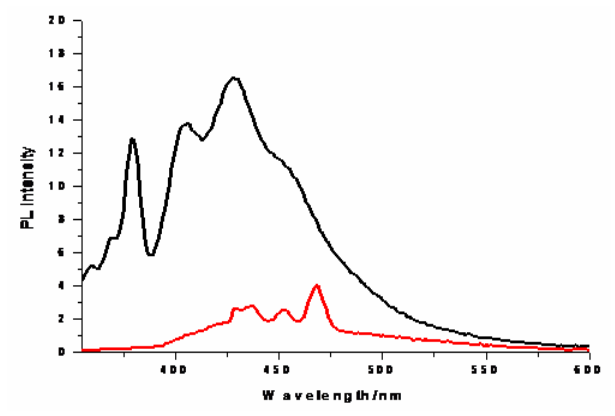

Fig. 12. PL spectra of $\left[\mathrm{Ni}(\mathrm{acac})_{2}\right.$ (phendione)] complex when excited at 340 (black) and $410 \mathrm{~nm}$ (red).

Therefore, the metal complexes with phendione and acac ligands showed varieties of characteristic PL peaks in UV, Visible and NIR regions in solution. The compounds that showed PL peaks in NIR regions may be assigned to octahedral geometry.

\subsection{Antibacterial activity assay}

The antibacterial activities of synthesized compounds were tested against five bacterium, namely Proteus mirabilis(a), Escherichia coli(b), Pseudomonas aeruginosa(c), Klebsiellapneumoniae(d) and Staphylococcus Aurius(e). The annular radius of the inhibitory zones created by the antibacterial agents (tested compounds) was measured [29]. The results of the antibiogram sensing ability of the synthesized compounds are given below in the following Table 2 and Fig. 13 for [Cr(acac) $)_{2}$ (phendione)]Cl complex.

The $\left[\mathrm{Cr}(\mathrm{acac})_{2}\right.$ (phendione)]Cl complex showed highest antibacterial activities against Escherichia coli (Table 2 and Fig. 13). The antibacterial activity results revealed that the [Zn(acac) $)_{2}$ (phendione)] complex showed highest antibacterial activities against Klebsiellapneumoniae. The highest antibacterial activity against Staphylococcus aureus is observed for $\left.[\mathrm{Zn} \text { (phendione })_{3}\right]\left(\mathrm{ClO}_{4}\right)_{2}$ complex. The $\left.[\mathrm{Ni} \text { (phendione })_{2}\right]\left(\mathrm{ClO}_{4}\right)_{2}$ complex showed highest antibacterial activities against Staphylococcus aureus. It is obvious from the antibacterial activity testing result that phendione related complexes showed enormous antibacterial activities. 
Table 2. Antibacterial activities of [Cr(acac) 2 (phendione) $] \mathrm{Cl}$ complex against pathogenic bacteria.

\begin{tabular}{lcccc}
\hline Bacterial culture & $\begin{array}{c}\text { Diameter of } \\
\text { inhibition zone } \\
\mathrm{D}_{\mathrm{iz}}(\mathrm{mm})\end{array}$ & $\begin{array}{c}\text { Diameter of well } \\
\mathrm{D}_{\mathrm{w}}(\mathrm{mm})\end{array}$ & $\begin{array}{c}\text { Ratio } \mathrm{R}= \\
\mathrm{D}_{\mathrm{iz}} / \mathrm{D}_{\mathrm{w}}\end{array}$ & Comments \\
\hline Proteus mirabilis & 24 & 6 & 4 & Resistance \\
Escherichia coli & 26 & 6 & 4.33 & Resistance \\
Pseudomonas aeruginosa & 25 & 6 & 4.17 & Resistance \\
Klebsiellapneumoniae & 21 & 6 & 3.5 & Resistance \\
Staphylococcus aureus & 25 & 6 & 4.17 & Resistance \\
\hline
\end{tabular}

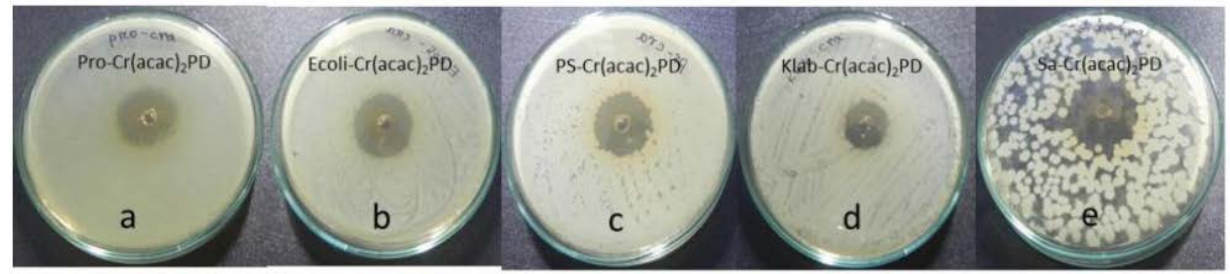

Fig. 13. Antibacterial activity of $\left[\mathrm{Cr}(\mathrm{acac})_{2}\right.$ (phendione) $] \mathrm{Cl}$ complex.

The huge antibacterial activities of the phendione related compounds can be attributed to the fact that phendione has free quinoid functional group with redox properties which can cause the bacterial cell breaking and binding to the protein synthesizing enzyme thus inhibiting the protein synthesis for bacterial growth resulting in the death of microbes. The $\left[\mathrm{Cr}(\mathrm{acac})_{2}\right.$ (phendione) $] \mathrm{Cl}$ complex showed the highest antibacterial activities among the metal complexes under investigation. The $\left[\mathrm{Cr}(\mathrm{acac})_{2}\right.$ (phendione)]Cl complex showed most potential antimicrobial activities against the bacteria Escherichia coli with an annular radius of the inhibitory zone, 4.33 and then against Pseudomonas aeruginosa (4.17) and Staphylococcus aureus(4.17), respectively.

\subsection{DNA binding studies}

DNA binding activities of the synthesized complexes were studied by agarose gel electrophoresis method [17]. The DNA binding was studied by varying time for the metal complexes of the phendione ligand. DNA was extracted from bacteria by extraction kit and the binding activity of the synthesized products were studied for both genomic and plasmid DNA. The result is shown in Fig. 14. It is apparent that all the metal complexes under investigation bind to DNA effectively. As seen in Lane $5,\left[\mathrm{Cr}(\mathrm{acac})_{2}\right.$ (phendione) $] \mathrm{Cl}$ complex intercalate into DNA less strongly then other complexes. It is also evident that $\mathrm{Zn}$ and $\mathrm{Ni}$ complexes not only intercalate into DNA strongly but also cause DNA degradation or cleavage after $2.5 \mathrm{~h}$.

The DNA binding activities of the metal complexes were also studied after $2.5 \mathrm{~h}$ of incubation with plasmid DNA. From the result it is obvious that the metal complexes bind to DNA such weakly that after $2.5 \mathrm{~h}$ cannot intercalate into DNA much except $\left.[\mathrm{Ni} \text { (phendione })_{2}\right]\left(\mathrm{ClO}_{4}\right)_{2}$. It is observed that $\left.[\mathrm{Ni} \text { (phendione })_{2}\right]\left(\mathrm{ClO}_{4}\right)_{2}$ complex not only 
intercalate into DNA but also causes DNA degradation or cleavage after $2.5 \mathrm{~h}$. This implies that $\left.[\mathrm{Ni} \text { (phendione })_{2}\right]\left(\mathrm{ClO}_{4}\right)_{2}$ complex is a better intercalated into DNA more rapidly than does the other complexes in case of plasmid DNA. The [Ni(phendione $\left.)_{2}\right]\left(\mathrm{ClO}_{4}\right)_{2}$ complex bind to plasmid DNA mostly through electrostatic interaction between the phosphate groups of DNA and the N-H group of the ligand. From the above results, we can come to the conclusion that most of the metal complexes under study easily cause DNA degradation or cleavage after $2.5 \mathrm{~h}$ with genomic DNA rather than plasmid DNA.

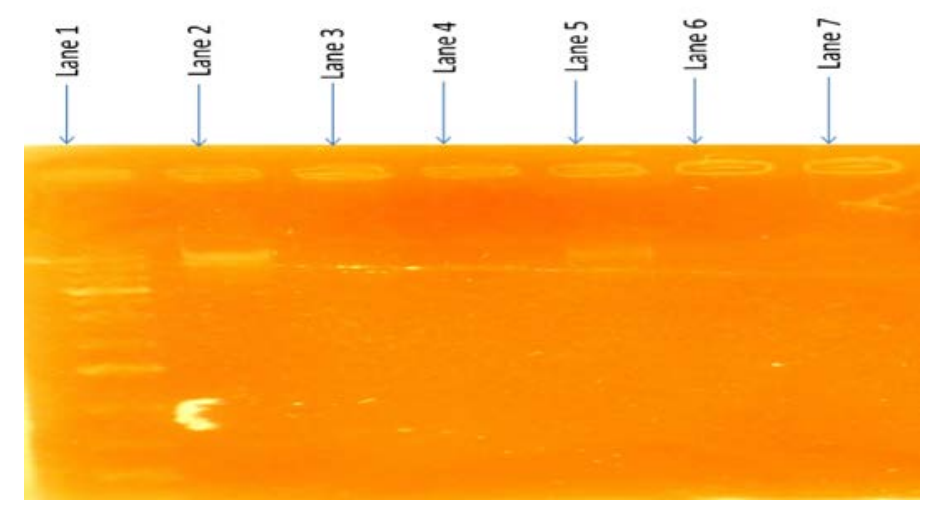

Fig. 14. DNA binding study of metal complexes after $2.5 \mathrm{~h}$ of incubation with genomic DNA. From left to right, lane 1 indicates DNA ladder, Lane 2-DNA control, Lane 3[Ni(phendione $\left.)_{2}\right]\left(\mathrm{ClO}_{4}\right)_{2}+$ DNA, Lane 4-[Zn(phendione) $\left.)_{3}\right]\left(\mathrm{ClO}_{4}\right)_{2}$ complex+DNA, Lane 5$\left[\mathrm{Cr}(\mathrm{acac})_{2}\right.$ (phendione) $] \mathrm{Cl}$ complex+DNA, Lane 6-[Zn(acac) $)_{2}$ (phendione) $]$ complex+DNA, Lane 7$\left[\mathrm{Ni}(\mathrm{acac})_{2}\right.$ (phendione)] complex+DNA.

Fig. 15 shows that the metal complexes also bind to genomic DNA effectively after $16 \mathrm{~h}$ of incubation and only Lane $5,\left[\mathrm{Cr}(\mathrm{acac})_{2}\right.$ (phendione)]Cl complex intercalate less into DNA. The Zn and Ni complexes not only intercalate into DNA but also cause DNA degradation or cleavage after $16 \mathrm{~h}$.

The DNA binding activities of the metal complexes were also studied after $16 \mathrm{~h}$ of incubation with plasmid DNA. This result is shown in the Fig 16. We can see that all complexes not only intercalate into DNA but also cause DNA degradation or cleavage after $16 \mathrm{~h}$. In summary, all the metal complexes can easily cause DNA degradation or cleavage after $16 \mathrm{~h}$ with plasmid DNA.

These apparent results can be rationalized in terms of both intercalation and degradation of DNA by the metal complexes under investigation. From the DNA binding study we observed that, the most effective intercalator is $\left.[\mathrm{Ni} \text { (phendione) })_{2}\right]\left(\mathrm{ClO}_{4}\right)_{2}$ complex, whose intercalation to DNA causes the inhibition of DNA intercalation of ethidium bromide. Thus the DNA band appears to be almost absent. All the metal complexes also effectively degrade or cleave DNA strands which are apparent from increased mobility of the DNA bands. Intercalation of metal complexes to plasmid DNA 
is observed after $16 \mathrm{~h}$ of incubation. However, in case of genomic DNA most metal complexes except $\left[\mathrm{Cr}(\mathrm{acac})_{2}\right.$ (phendione) $] \mathrm{Cl}$ intercalated rapidly only after $2.5 \mathrm{~h}$ of incubation.

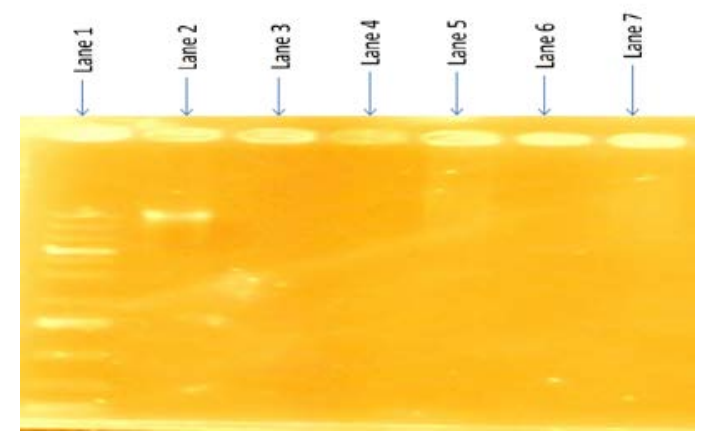

Fig. 15. DNA binding study of metal complexes after16 h of incubation with genomic DNA. From left to right, lane 1-DNA ladder, Lane 2-DNA control, Lane 3-[Ni(phendione $\left.)_{2}\right]\left(\mathrm{ClO}_{4}\right)_{2}+\mathrm{DNA}$, Lane 4-[Zn(phendione) $\left.)_{3}\right]\left(\mathrm{ClO}_{4}\right)_{2}$ complex+DNA, Lane 5-[Cr(acac) $)_{2}$ (phendione) $] \mathrm{Cl}$ complex+DNA,

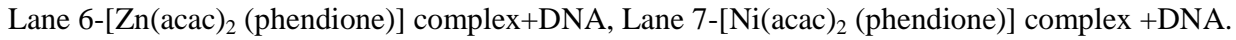

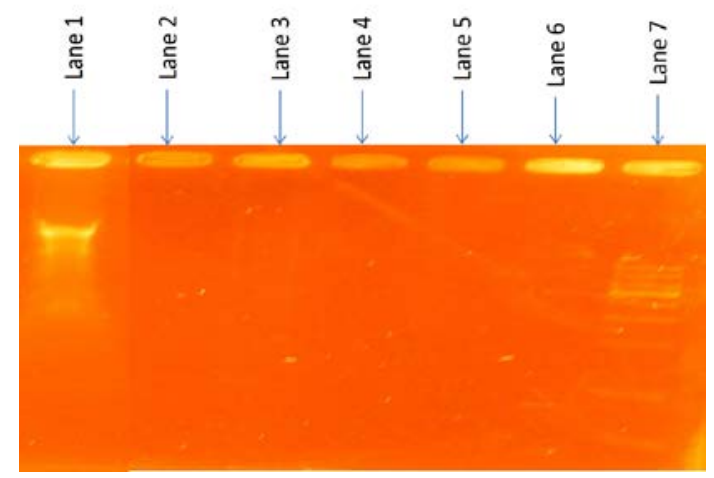

Fig. 16. DNA binding study of metal complexes after $16 \mathrm{~h}$ of incubation with plasmid DNA. From left to right, Lane 1-DNA control, Lane 2-[Ni(phendione) $\left.)_{2}\right] \quad\left(\mathrm{ClO}_{4}\right)_{2}+\mathrm{DNA}$, Lane 3$\left.[\mathrm{Zn} \text { (phendione) })_{3}\right]\left(\mathrm{ClO}_{4}\right)_{2}$ complex+DNA, Lane 4-[Cr(acac) $)_{2}$ (phendione) $\mathrm{Cl}$ complex+DNA, Lane 5-[Zn(acac) ${ }_{2}$ (phendione)] complex+DNA, Lane 6-[Ni(acac) $)_{2}$ (phendione)] complex +DNA, lane 7DNA ladder.

\section{Conclusion}

The transition metal complexes [Cr(acac) ${ }_{2}$ (phendione)]Cl, [Zn(acac) $)_{2}$ (phendione)], $\left[\mathrm{Ni}(\mathrm{acac})_{2}\right.$ (phendione) $\left.], \quad[\mathrm{Zn} \text { (phendione })_{3}\right]\left(\mathrm{ClO}_{4}\right)_{2}$ and $\left[\mathrm{Ni}(\text { phendione })_{2}\right]\left(\mathrm{ClO}_{4}\right)_{2}$ were synthesized from phendione. The phendione ligands and its metal complexes were characterized by FTIR, UV-Visible spectroscopy and PL study and in some cases by

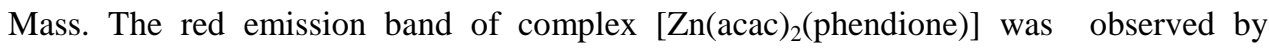
excitation at $250 \mathrm{~nm}$. DNA binding activities of the complexes were studied by DNA Gel 
Electrophoresis. DNA binding studies of the synthesized compounds showed that the metal complexes are strong DNA binding and cleaving agents. The [Ni(phendione) $)_{2}$ ] $\left(\mathrm{ClO}_{4}\right)_{2}$ complex was the most effective DNA binding and cleaving agent and $[\mathrm{Cr} \text { (acac) })_{2}$ (phendione)]Cl complex showed relatively lower affinity for DNA binding and cleaving. The metal complexes easily caused DNA degradation or cleavage (after $2.5 \mathrm{~h}$ ) with genomic DNA rather than with plasmid DNA. Intercalation of most of the metal complexes to plasmid DNA was observed after $16 \mathrm{~h}$ of incubation. Antimicrobial activity studies revealed that, all metal complexes of phendione showed efficient resistance to bacteria. The $\left[\mathrm{Cr}(\mathrm{acac})_{2}\right.$ (phendione)]Cl complex showed most potential antimicrobial activities against the bacteria Escherichia coli with an annular radius of the inhibitory zone, 4.33 and then against Pseudomonas aeruginosa (4.17) and Staphylococcus aureus(4.17), respectively. The transition metal complexes can cause the bacterial cell breaking and binding to the protein synthesizing enzyme, thus inhibiting the protein synthesis for bacterial growth resulting in the death of microorganisms.

\section{References}

1. M. A. Subhan, Y. Hasegawa, T. Suzuki, S. Kaizaki, and Y. Shozo, Inorg. Chim. Acta 362, 136 (2009). http://dx.doi.org/10.1016/j.ica.2008.03.093

2. J. R. Anacona, T. Martell, and I. Sanchez, J. Chil. Chem. Soc. 1, 50 (2005).

3. R. E. Devis, Principles of chemistry (Univeristy of Texas, Austin, 1984).

4. F. A. Cotton, Advanced Inorganic Chemistry, A Comprehensive Text, $2^{\text {nd }}$ Edition (John Wiley \& Sons, New York, 1966).

5. F. Akagi, H. Kawaguchi, and T. Matsou, J. Am. Chem. Soc. 127, 11936 (2005). http://dx.doi.org/10.1021/ja053740m

6. L. Calucci, G. Pampaloni, C. Pinzino, and A. Prescimone, Inorg. Chim. Acta 359, 3911 (2006). http://dx.doi.org/10.1016/j.ica.2006.04.040

7. T. S. Eckert and T. C. Bruice, J. Am. Chem. Soc. 105, 4431 (1983). http://dx.doi.org/10.1021/ja00351a049

8. C. Desroches and L. Ohrstrom, Acta Cryst. 63, 190 (2007). http://dx.doi.org/10.1107/S010876810605244X

9. N. M. Shavaleev, L. P. Moorcraft, S. J. A. Pope, Z. R. Bell, S. Faulkner, and M. D. Ward, Chem. Eur. J. 9, 5283 (2003). http://dx.doi.org/10.1002/chem.200305132

10. R. Kobetic, D. Gembarovski, G. Baranovic, and V. Gabelica, J. Mass Spectrom. 43, 753 (2008). http://dx.doi.org/10.1002/jms.1372

11. S. R. Hosseinian, S. A. J. Fatemi, H. Hadadzadeh, M. Weil, and A. D. Khalaji, X-ray Structure Analysis Online. 24, 287 (2008).

12. M. Wen, E. Kejia, M. Munakata, Y. Suenaga, T. K. Sowa, M. Maekawa, and S. G. Yan, Mol. Cryst. Liq. Cryst. 457, 203 (2006). http://dx.doi.org/10.1080/15421400600598768

13. D. M. Boghaei and F. Behzadian-Asl, J. Coord. Chem. 60, 347 (2007). http://dx.doi.org/10.1080/00958970600862151

14. J. Onuegbu, R. J. Butcher, C. Hosten, U. C. Udeochu, and O. Bakare, Acta Cryst. Sect E, 65, m1119 (2009). http://dx.doi.org/10.1107/S160053680903222X

15. F. Calderazzo, F. Marchetti, G. Pampaloni, and V. Passarelli, J. Chem. Soc. 24, 4389 (1999).

16. C. G. Pierpont and C. W. Lange, Progr. Inorg. Chem. 41, 331 (1994).

17. M. A Subhan, M. S. Rahaman, K. Alam, and M. M. Hasan, Spectrochimica Acta A: Mol. Biomol. Spectroscopy 118, 944 (2014). http://dx.doi.org/10.1016/j.saa.2013.09.110

18. J. Onuegbu, R. J. Butcher, C. Hosten, U. C. Udeochu, and O. Bakare, Acta Cryst. E 64, m403 (2008). http://dx.doi.org/10.1107/S1600536808000846 


\section{Metal Complexes Containing Phendione Ligand}

19. J. L. Yun, C. Hui, X. Y. Yi, J.N. Yu, and N. Liang, Inorg. Chim. Acta 359, 3807 (2006). http://dx.doi.org/10.1016/j.ica.2006.05.015

20. L. Fengyan, X. Lin, W. Yongge, G. Guanggang , F. Lihua, and L. Zhikui, Inorg. Chim. Acta 359, 3795 (2006). http://dx.doi.org/10.1016/j.ica.2005.10.050

21. Z. B. Zheng, Z. M. Duan, J. X. Zhang, and K. Z. Wang, Sensors Actuators B-Chem. 169, 312 (2012). http://dx.doi.org/10.1016/j.snb.2012.05.003

22. G. Bandoli, A. Dolmella, G. G Lobbia., G. Papini, M. Pellei, and C. Santini, Inorg. Chim. Acta 359, 4036 (2006). http://dx.doi.org/10.1016/j.ica.2006.04.010

23. M. Faisal, S. B. Khan, M. M. Rahman, A. Jamal, K. Akhtar, and M. M. Abdullah, Mater. Sci. Technol. 27, 594 (2011). http://dx.doi.org/10.1016/S1005-0302(11)60113-8

24. R. Kobetic, D. Gembarovski, G. Baranovic, and V. Gabelica, J. Mass Spectrom. 43, 753 (2008). http://dx.doi.org/10.1002/jms.1372

25. M. A. Subhan, T. Suzuki, and S. Kaizaki, J. Chem. Soc. Dalton Trans. 4, 492 (2001). http://dx.doi.org/10.1039/b007369p

26. M. J. Bennett, F. A Cotton, R. Eiss, Acta Cryst. B24, 904(1968). http://dx.doi.org/10.1107/S0567740868003390

27. Y. Xie, P. L. Irwin, T. Jin, and X. Shi, Appl. Environ. Microb. 77, 2325 (2011). http://dx.doi.org/10.1128/AEM.02149-10

28. A. R. Rezvani, H. Saravani, and H. Hadadzadeh, J. Iran. Chem. Soc. 7, 825 (2010).

29. A. W. Bauer, W. M. Kirby, J. C. Sherris, and M. Turck, Am. J. Clin. Pathol. 45, 493 (1966). 